\title{
Prevalence of Bacterial Infections and the use of Multiplex Pcr Assay for Rapid Detection in Cultured Fish in Ghana.
}

Rhoda Lims Diyie ( $\square$ ho_lims@yahoo.com )

CSIR-Water Research Institute https://orcid.org/0000-0002-2186-708X

Dennis W. Aheto

University of Cape Coast

Mike Y. Osei-Atweneboana

CSIR, Water Research Institute

Emmanuel Armah

CSIR-Water Research Institute

Kobina Yankson

University of Cape Coast

\section{Research Article}

Keywords: Fish Diseases, Molecular Diagnosis, Bacterial Pathogens, Physico-chemical Parameters, Ghana

Posted Date: March 18th, 2021

DOI: https://doi.org/10.21203/rs.3.rs-311895/v1

License: (c) (i) This work is licensed under a Creative Commons Attribution 4.0 International License.

Read Full License 


\section{Abstract}

The modern and rapid avenue for detecting pathogens provided by molecular genetic techniques including polymerase chain reaction (PCR) was explored in the present study to identify prevalent disease pathogens, from six aquaculture farms and in two commonly cultured fish in Ghana. The specific detection was carried out directly on clinical samples of naturally infected fish (O. niloticus and $C$. gariepinus) based on syber-mix reaction protocol in traditional PCR. Molecular diagnostic techniques allowed the detection of six most common and important bacteria pathogens in aquaculture farms in Ghana. Also, three of the pathogens (Streptococcus agalactiae, Streptococcus iniae and Staphylococcus aureus) were simultaneously isolated in a multiplex reaction. The results indicated $90 \%-100 \%$ sensitivity and specificity for each of the six bacterial pathogens tested. Streptococcosis and motile aeromonad septicemia were found to be highly prevalent in most aquaculture farms in Ghana with severity in infections traced to the $85.7 \%$ and $14.9 \%$ co-infections with all six target pathogens in catfish and tilapia respectively. Prevalence rate of infections significantly correlated with variations in salinity, conductivity and dissolved oxygen concentrations in the thermal stressed condition of the culture water.

\subsection{Introduction}

Fish reared in aquaculture facilities are highly susceptible to infectious diseases caused by a diverse collection of pathogens (Real, 1996). Bacterial pathogens however, represents the major cause of these infectious diseases and mortalities in fish under such confined conditions (Post, 1989; Zorrilla, et. al., 2003). Although pathogenic bacteria have been implicated in fish diseases, only a relatively small number are responsible for important economic losses in cultured fish worldwide, belonging to the genera Vibrio, Aeromonas, Flavobacterium, Yersinia, Edwardsiella, Streptococcus, Lactococcus, Renibacterium, and Mycobacterium (Austin and Austin, 1999). These are prominent microbiota in freshwater reservoirs where together with other microorganisms, act as natural bio-filters that promote self-purification of water bodies (Suthikrai et al., 2012). Despite being present as a necessity in normal microflora and hydrobionats inhabiting fish reservoirs (Kompanets et al; 1992), they frequently cause problems in both wild and cultured fish (Cipriano, 2001). They are known to heavily affect the Food Conversion Ratio (FCR), reduce marketable product and damage production and processing efficiency, as well as causing large fish kills (Austin and Austin, 1999). Thus, most intensive fish farming operations suffer from between six and eight major production diseases, such as: Streptococcosis, Columnaris, Enteric Septicemia, Vibriosis, Motile Aeromonas Septicemia (MAS), Enteric Red Mouth disease and Mycobacteriosis. These diseases in aquaculture systems have increased significantly over the last decade thus representing the largest single cause of economic losses in aquaculture (Meyer, 1991). It constitutes a huge threat to fish farming and requires effective control strategies to ensure true sustainability of the aquaculture industry (Komar et al, 2018).

To effectively control these diseases, require the identification of the presence of specific pathogen and monitoring of the changes in their abundance. However, in Ghana, the identification of bacteria pathogens from fish is mostly based on conventional microbiological methods, by isolation and culturing of bacteria 
which is technically demanding, and often limited by the length of time required to complete the assays. In addition, there are lack of pure isolates to affiliate the identification of unfamiliar and newly identified species. The DNA-based technologies, including Polymerase Chain Reaction (PCR) has helped in overcoming major challenges faced by culture-based techniques (Altinok and Kurt 2003). Also, multiplex (m-PCR) assay, a DNA-based technology acting as an extension of the traditional PCR allows simultaneous amplification of multiple DNA sequence or targets in a single reaction, using multiple primer sets (Mata et al., 2004). This approach saves time and effort without compromising the utility of the experiment. It also has the potential to control false negatives, conserve reagents and DNA templates that may be in short supply.

The application of multiplex assays in disease diagnosis is highly vital since more often, fish diseases are caused by the synergistic interactions between two or more taxa, and not by a single taxon (Kotob et al, 2017). It has been established that streptococcal infections for instance, are not a single entity, but a cluster of similar infections caused by Gram positive cocci which belong to several genera, including streptococci (Fadaeifard et al., 2018). Generally, the natural environments harbour a wide diversity of micro-organisms, and may all utilize the opportunity to infest a fish host under favourable environmental conditions. However, in practice, single pathogen identification is usually deployed in fish disease diagnosis research. Thus, based on this characteristic feature in the mode of infections, this study also targeted the isolation and identification of multiple pathogens likely to cause disease in cultured fish in Ghana. Thus, six of the organisms that have been implicated in diseases of farmed warm-water fish were investigated to ascertain their level of impact on cultured fish in Ghana. The effect of physicochemical parameters on bacterial infection in these fish species were also assessed. Rapid diagnoses of fish diseases with molecular tools to enhance effective management of diseases in aquaculture systems in Ghana was therefore the basis for this study.

\subsection{Materials And Methods}

\subsection{Study Areas}

Fish samples were taken from 6 aquaculture farms ( 4 tilapia farms, 1 catfish farm, 1 both tilapia and catfish farm) located within the southern part of Ghana and representing three regions (Central, Eastern and Greater Accra regions), where vibrant aquaculture farms of both cage and pond systems with reported history of disease conditions (Alhassan et al, 2018) are located. The locations of the farms based on their GPS are shown in Figure 1. Three of these farms were semi -intensive systems operating under the pond system of farming, (F3, F5, F6) whiles the other three were operating under the intensive and cage system of farming (Fi, F2, F4). Per the scale of production, farms selected were representative of small $(F 5, F 6)$ medium (F3, F4) and large (F1, F2) scale aquaculture farms in Ghana.

\subsection{Sample Collection}


A total of 575 fish tissues (tilapia) were obtained from 200 clinical and 200 non-clinical specimens of tilapia and 75 tissues from 25 diseased and 25 healthy catfish. Sampling was done aseptically, by avoiding contamination from external sources, thus quickly transported in cold boxes to the laboratory (CSIR-Water Research Institute). Physico-chemical parameters (Temperature, Salinity, Conductivity, Dissolved Oxygen and $\mathrm{pH}$ ) of the water were measured in-situ per each of the four sampling sessions, using a water quality testing kit (Hanna Instruments, HI 98129, Woonsocket RI, USA). Measurements were taken from a minimum of three ponds/cages from each farm with parameters taken from 3 points per pond/cage and averages taken to ensure accuracy of results. Three replicates of water samples were taken per each sampling session, from each farm for microbial analysis.

\subsection{Sample Preparation and DNA Extraction}

Fish samples were subjected to clinical and post mortem examinations following Austin and Austin (1999) method. Briefly, for external examination, skin surface abnormalities were noted with photographs of anomalies taken. Both eyes were examined with a hand lens for changes in size, location in orbit (sunken, protruding, level), and changes in colour. Gills were examined by removing the operculum and changes in colour noted. Internal organs were also observed after dissection for changes in size, colour, shape and lesions. Morphometric parameters (length, weight) of the fish were taken prior to dissection. Fish dissection was as described by Noga, (1996). Tissues examined were liver, gills, kidney, including diseased portions, gut as well as skin washes. Fifty (50) mg of the tissues were prepared as starting materials for DNA extraction whiles water samples, skin washes and guts content dissolved in $100 \mathrm{ml}$ of distilled water were filtered, and portions of the air-dried filter paper cut for DNA extraction. With little modifications, the Qiagen DNA extraction protocol was used to extract the DNAs from the fish materials and water samples. Briefly, $50 \mathrm{mg}$ of tissues were homogenized in 45ul of Animal Tissue Lysis (ATL) buffer with $5 \mathrm{ul}$ of Proteinase $\mathrm{K}$ and incubated overnight at $56^{\circ} \mathrm{C}$. The extraction procedure was continued as directed by manufacturer's instructions.

\subsection{Single/Multiplex PCR Assays: Detection of Universal and Specific Bacteria Species in Fish Samples}

All DNA samples were screened for the presence of bacteria using universal primers U63/1378 (Zhang et al., 2016), targeting the $16 \mathrm{~S}$ rRNa gene of bacteria. The traditional PCR reaction protocol had a total reaction mixture of 10ul: $5 \mathrm{ul}$ of Syber Green enzyme, $10 \mathrm{uM}$ of $0.3 \mathrm{ul}$ of each primer set, $2.4 \mathrm{ul}$ nuclease free water and $2 \mathrm{ul}$ of DNA. The cycling conditions had an initial denaturation of $94^{\circ} \mathrm{C}$ for $3 \mathrm{mins}$ followed by 30 cycles of $94^{\circ} \mathrm{C}$ denaturation, $50^{\circ} \mathrm{C}$ annealing, both at 45 seconds each and at $72^{\circ} \mathrm{C}$ extension for 1 minute. A final extension was set at $72^{\circ} \mathrm{C}$ for 5 minutes. The samples that amplified for universal bacteria were then screened for the presence of the six target species (Streptococcus iniae, Streptococcus agalactiae, Staphylococcus aureus, Aeromonas hydrophilla, Edwardsiella ictaluri, Flavobacterium columnare) in a single-plex assay. Selection of target species was based on the fact that disease symptoms as observed 
were characteristic of these extracellular bacteria. All primers used as described in previous publications (Mangala et al., 2002; Griffin et al., 2011; Robert et al., 2012) were synthesized by ISOGEN Bioscience BV (Maarssen, The Netherlands. Primer sets were all tested for specificity, sensitivity, optimal annealing temperature and primer efficiency as previously described by Bustin, (2010) and Bustin et al., (2009). The detailed primer sequences and additional information are provided in Table 1. The reaction protocols and cycling conditions were modified to amplify one set of the bacteria in a multiplex PCR (m-PCR)

(Streptococcus iniae, Streptococcus agalactiae and Staphylococcus aureus). The m-PCR was optimized for the simultaneous detection of the three microorganisms by testing two or more concentrations of primer $(0.5,1,1.5$, and $2 \mathrm{uM})$, DNA or optimization of cycling conditions, and then running over a gradient annealing temperature. Negative controls, where template DNA in the reaction were replaced with distilled water was included in reactions. Also, positive controls of pure bacteria colonies (Streptococcus, Staphylococcus: clinical isolates from diseased Nile tilapia, isolated at the Council for Scientific and Industrial Research-Water Research Institute (CSIR-WRI) Microbiology laboratory, Accra, Ghana) were included in the reaction as a quality control measure. Amplified PCR products were visualized by $2 \%$ agarose gel electrophoresis. Briefly, PCR products mixed with loading dye was loaded into the gel wells and allowed to run on electric fields moving from the positively charged electrodes to the negatively charged electrodes. The resulting amplifications were visualized as bands using a UV Trans illuminator (BioDoc-it imaging system, Upland, USA). Samples were also sequenced to further ascertain the specificity of target species.

\subsection{Statistical Analysis}

Prevalence rates, that is, the percentage of fish in a population that have the disease or percentage of specific species of pathogen in a fish were estimated by GenAlEx 6.5: genetic analysis in Excel (Peakall R, 2012). ANOVA was used to test the mean significant difference of bacterial occurrence among individuals, farms and the various tissues analyzed. Pearson's Correlation co-efficiency was used to determine the correlation between physico-chemical parameters and prevalence rate of infections. The significance level was set at $P<0.05$. Sequenced results were compared against the GenBank database of the National Centre for Biotechnology Information (NCBI) by using the BLAST (Basic Local Alignment Search Tool) program (http://blast.ncbi.nlm.nih.gov).

\subsection{Results}

\subsection{Clinical/Postmortem Findings}

Per the clinical and postmortem examination, major clinical features like ulcerative skin, dark skin colorations, detachment of scales, exophthalmia, cloudy eyes, ascites, abscess, varied sizes of red patches on the body surface, hemorrhages, and gill necrosis were observed in tilapia samples. Fin/barbel erosions, inflamed vent, septicemia, abdominal distension with sero-hemorrhagic fluids and enlargement 
of liver were also observed in catfish samples. These diseased fish samples showed one or more of the signs listed above depending on the severity stage of disease.

\subsection{Morphometric and Water Quality Analysis}

Based on morphometric analysis (Table 2), diseased fish samples obtained from the various farms particularly that of tilapia, were predominantly juveniles, within the size range of $8-21 \mathrm{~cm}$ (Fig 2). Water quality parameters were generally within optimum ranges although some high and low values were recorded for some parameters on some farms (e.g. Dissolved Oxygen (DO)). $\mathrm{pH}$ values recorded were between $6.47 \pm 0.55-10.44 \pm 0.15$, DO $(3.0 \pm 0.4-5.4 \pm 0.72 \mathrm{mg} / \mathrm{L})$, temperature $\left(29 \pm 0.9-33.4 \pm 0.28^{0} \mathrm{C}\right)$, Salinity (34- $582 \mathrm{ppm}$ ) and conductivity between 68 and $1162 \mu \mathrm{S} / \mathrm{cm}$ (Table 3). Significant positive correlations were obtained between the prevalence rate of infections and salinity, DO and conductivity of culture water.

\subsection{Molecular Diagnoses of Bacterial Infections}

Samples screened for the presence of bacteria with universal bacteria primers included tilapia, catfish, and water samples from pond and cages obtained from the various farms. A total of 215 out of 225 fish samples were observed to be habouring bacteria in the various tissues (Table 4). The occurrence of bacterial infections was $95 \%$ and $100 \%$ in tilapia and catfish respectively. Water samples also recorded the presence of bacteria from each farm at an average prevalence rate of $33.3 \%$. The prevalence rate of pathogens from the various tissues analyzed was also highest in the catfish (93.3\%), with tilapia recording $70 \%$ prevalence (Table 4). The prevalence rates of specific bacterial infections in both tilapia and catfish specimens are shown in table 5 . The specific species of bacteria isolated among the bacteriapositive samples, recorded high prevalence among the catfish samples than the tilapia, with significantly $(p<0.05 \%)$ high levels of multiple infections. Streptococcus iniae was the bacteria species with highest prevalence rate recorded in both catfish (93.33\%) and tilapia (88\%), as well as in water samples (32\%). Streptococcus agalactiae was the second highest species recorded in tilapia samples at a prevalence of $72 \%$, whereas Staphylococcus aureus was second highest recorded for catfish (86.67\%). Aeromonas hydrophila occurred at a prevalence rate of $44 \%$ in catfish samples, although recorded the lowest prevalence in tilapia samples (12\%). Flavobacterium columnare was the lowest recorded in catfish samples (22\%). There was no record of Staphylococcus aureus in water samples on all farms. The diseased portions (skin lesions, ulcerations, eye in specimens with exophthalmia, brain from samples showing erratic movements, liquid from septicemia) among the tissues analyzed recorded the highest prevalence of bacterial infections (Fig 3). Bacterial infections with target species were recorded in all the farms studied (Fig 4). Relatively low prevalence rates were recorded in farms 1 and 2 representing cage/intensive systems of farming, with high stocking densities but practicing periodic and routine vaccinations respectively. Comparatively, high infection levels were recorded in farms 4,5 , and 6 , also representing semi-intensive/pond systems of farming, with low to no health management practices. Per the clinical signs and results from laboratory test, fish samples were diagnosed with streptococcosis 
disease whereas all other infections particularly, columnaris in tilapia and Motile Aeromonad Septicemia (MAS) in catfish took advantage of the susceptible state of the fish to proliferate.

The images of the positive amplifications of universal and specific bacteria in single-plex and multiplex reactions are shown in the Figures 5 and 6 respectively. The sensitivity of the PCR assay for the isolated targets was as low as $1 \mathrm{pg}$ of DNA and less than $10 \mathrm{CFU}$. Blast report at nucleotide level showed 100, 98, $97,90,92$, and 90 percent identity with Streptococcus agalactiae, Streptococcus iniae, Staphylococcus aureus, Aeromonas hydrophilla, Edwardsiella ictaluri and Flavobacterium columnare respectively. Generally, the prevalence rate of these pathogens was higher in diseased fish than in the apparently healthy fish (Figure 7). However, this difference was not significant with a P value of 0.14 . The uninfected diseased samples, mainly showed genetic based symptoms like deformities and also represented individual specimens that gave negative amplification for target species.

\subsection{Discussion}

We report a molecular-based approach for diagnosing fish infections and the associated diseases in the most predominantly cultured fish species from some selected farms in Ghana. This was undertaken following the urgent need for a fast and reliable method of disease diagnosis in the country to help curb the fast rise in mass mortalities resulting from diseases in recent years. Thus, in this study, naturally occurring diseased tilapia and catfish with clinical signs (erratic swimming, lethargy, darkening of the skin, exophthalmia, skin lesions and ulcerations, eroded barbells, ascites, septicemia, abscess, gill necrosis, enlargement of liver) associated with bacterial diseases were investigated by PCR in order to identify the etiological agents. In aquaculture, diseases are known to be agents of mortality in all life stages of fish, once conditions are not favorable. However, juveniles or early growth stages are the most susceptible stages for diseases in fish (Houde, 1987; Sifa and Mathias, 1987). Morphometric analysis of diseased fish samples in this study corroborates these assertions, as diseased samples, particularly tilapia specimens were predominantly among the juveniles.

Fish are by their nature submerged in their environment, thus tend to have the percentage of bacterial genera present in their skin mucus almost the same as those in the environment. The results from this study showed that, almost all the bacterial pathogens detected on the fish were also present in the water in which they were cultured. The fish mucosal immunity made up of the skin and gut serve as the first barrier to infections (Maaser and Kagnoff, 2002) but also constitute a large area for the possible invasion of pathogens. Thus, the skin, the gut and by extension the diseased portion (dp) recorded significantly high bacterial invasion $(P<0.05)$ of $32.33 \%, 31.44 \%$ and $34.25 \%$ respectively. The diseased portions, as labelled in this study were mainly ulcerative skin lesions and lesion from effective parts such as the eyes, fins, and gills necrosis, also exposed to the fish environment as the skin. The other organs, mainly internal (liver, kidney,) harbored less bacterial pathogens (Fig 3) supporting the claim that detection of pathogens in the gills and mucosal areas of fish are more sensitive than in the muscle and other internal organs. Hence, an important aspect of the pathogenesis of some infections like columnaris constitutes the adherence of the bacteria to the gills (Decostere et al., 1999). 
Direct isolation of bacteria from diseased fish without prior culturing was possible in a single-plex PCR reaction. Unlike in many research works where Taq buffer and polymerase were used in similar reactions (del Cerro et al., 2002; Mata et al., 2004), this work used a syber-mix reaction protocol which made it a better option as it reduced bench time and further increased the ease and speed in diagnosis. The protocol was highly sensitive with a minimum of $1 \mathrm{pg}$ of template DNA. The multiplex PCR (M-PCR) protocol developed was able to simultaneously determine the presence of target pathogens ( $S$. agalactiae, $S$. iniae and $S$. aureus). Thus, in a single reaction, three important pathogenic species of bacteria predominantly involved in disease outbreak in aquaculture farms could be identified. The protocol represents a good and fast diagnostic tool as it also gave opportunity of knowing when only one, two, all three or none of the target species are present in a sample (Fig 6). The m-PCR protocol was found to be $100 \%$ specific to target species as there was no amplification of any bacterial DNA after series of reactions using the same primer sets against different bacteria species. It also demonstrated a 100\% concordance with traditional phenotypic identification systems. Sequenced data confirmed the specificity of target species with $90-$ $100 \%$ percentage identity from blast result from NCBI. Application of this protocol was practically easy, less tedious and enhanced the duration for diagnosis and the number of samples analyzed in minimum sample volume. Laboratory testing is the ultimate means of diagnosing fish infections, hence, this protocol could better help in rapid identification of disease pathogens. Particularly, considering the fact that all previous studies on bacterial infections in fish in Ghana using mainly culture-based methods, identified most pathogens to genus level and could not trace it down to a particular species or strain as causative agent of specific diseases (Takyi et al., 2012; Ampofo, 2000)

Multiple or co-infections were confirmed in the study by the presence of more than one pathogenic bacterium in an individual fish. Tilapia samples showed multiple infections with all six target species; $S$. iniae, S. agalactiae, S. aureus, Aeromonas hydrophila, Edwardsiella ictaluri, and Flavobacterium columnare. Also, in the catfish, all six species of bacteria were recorded with significantly higher $(P<0.05)$ prevalence rates and intensity of infections compared to tilapia. These multiple infections in the catfish were highly consistent with the advanced state of the clinical signs (septicemia) shown in the diseased samples obtained. Multiple infections here thus substantiate the assertion that disease is caused by the synergistic interactions between two or more taxa, and not by a single-taxon (Kotob et al, 2017). Diagnosed individuals in this study were consistent with those reported in other studies (Mohamed et al., 2014; Iregui et al., 2014; Marcusso et al., 2015).

The genus Streptococcus is one of the most important Gram-positive bacteria (Conroy, 2009; Jimenéz, 2010) in aquaculture systems. Within this, the species $S$. agalactiae is the most prevalent worldwide (Sheehan et al., 2009). S. iniae is also a predominant pathogen in both tilapia and catfish. From the results, $S$. iniae, was the most predominant species affecting $93.33 \%$ of catfishes and $88 \%$ of tilapia fish samples followed by $S$. agalactiea. These species of Streptococcus isolated in the study are typical pathogens implicated in warm-water streptococcosis. Streptococcus infections particularly S. iniae, are known to be associated with outbreaks that occur at water temperatures above $15^{\circ} \mathrm{C}$. As observed, all the ponds and cages recorded a temperature higher than $15^{\circ} \mathrm{C}$ and hence were affected by warm-water streptococcosis. Particularly, the catfishes were cultured in a pond of relatively high temperature and 
slightly above the recommended values, hence had severe multiple bacterial infections as compared to tilapia. When Budiati et al., (2015) assessed the microbial quality of catfish and tilapia from wet markets and ponds, they observed that higher bacterial load in fishes corresponded to high temperatures of pond. Similar assessment was made by Kouamé et al., (2014) when they studied the aquaculture potential of fish in various rearing systems in Ivory Coast and noted that, high temperature of the ponds had effects on fish growth rate.

With regards to prevalence, $S$. aureus was second to S. iniae in catfish. It affected $86.67 \%$ of catfishes and $14.78 \%$ of Tilapia. Staphylococci in fish and fish products has been traced from handlers and fish farmers (Singh and Kulsherestha, 1993). specifically, catfish used in this study as observed had experienced several human handlings during sorting, harvesting and packaging of ideal size for the market with those below marketable sizes returned to ponds. Also coupled with the fact that $\mathrm{S}$. aureus was the only bacterial pathogen that was not recorded from the culture water samples obtained for this study, humans could therefore be confirmed as the direct source of $S$. aureus on the fish.

Aeromonas hydrophila is the causative agent of motile aeromonad septicemia (MAS). The symptoms of MAS include swelling of tissues, dropsy, red sores, necrosis, ulceration and haemorrhagic septicemia (Ibrahem et al., 2008; Swann. And White, 1914). Almost all these signs were shown by the diseased catfish. The presence of $A$. hydrophila, and similarly of E. ictalluri by itself, is not indicative of disease but stress often considered to be a contributing factor in the outbreak of disease caused by these bacteria (Nils kautsky et. al, 2000). Elevated water temperature, decreased dissolved oxygen concentration, or increased ammonia and carbondioxide concentrations have been shown to promote stress in fish and trigger MAS (Ibrahem et al., 2008; Swann and White, 1914) and from this study, co-infection with other pathogenic bacteria further promotes this condition.

In tilapia culture, four major bacterial diseases have so far been identified as most important to aquaculture production namely: Streptococcus agalactiae, Streptococcus iniae, Flavobacterium columnare and Francisella sp (Komar et al., 2018). Results from this study contributes to these findings as three of these pathogens were found to be prevalent in Ghanaian aquaculture facilities. Although at various prevalence rates $(46 \%, 39 \%, 46 \%, 74 \%, 75 \%, 100 \%)$, all farms recorded the presence of these pathogens. Farms from which samples were taken were a good representation of large scale, mid to low scale operation systems in Ghana thus, corresponding to intensive to semi-intensive systems of fish farming. Farming intensity, good husbandry practices and maintaining optimum water quality was found to be a challenge in some of the farms, hence most of the bacterial infections triggered by suboptimal water quality and environmental conditions like Flavobacterium columnare, Aeromonas hydrophila, and Edwardsiella ictaluri were prevalent in this study.

Generally, pathogen load in samples obtained from ponds (all the catfishes and some tilapia samples) were higher than those from the cages. The source of these high prevalence of target pathogens was also traceable to the pond water as there was less flushing in the pond compared to the increased flushing in the cages. This reflected in the slightly anoxic conditions recorded in most of the ponds. Generally, 
frequent flushing of ponds reduces the accumulation of benthic communities in the pond, which in turn reduces bacterial load in the water, and subsequently in the fish. However, under poor husbandry practices, where change of fish pond water is rarely done, excessive accumulation of waste feed and high fecal material results in increased bacterial populations, and as an indicator the $\mathrm{pH}$ would be acidic (Mente et al., 2006). It was observed from the farms, particularly from the catfish pond, that it had huge accumulation of organic material and was visibly green colored, an evidence of huge quantity of algal bloom, hence water quality indicated values within the anoxic and acidic ranges as well as high conductivity and salinity (Table 3), This poor water quality therefore significantly correlated with the high prevalence of co-infections (Table 6).

Prevalence rate of bacterial pathogens among diseased and healthy fish samples were not significant. However, quantitative PCR analysis detailing the actual concentrations of pathogens in both diseased and healthy fish are reported elsewhere. The public health implication in consuming physically healthy but infected fish from various farms may be of high concern and the proper treatment of fish prior to consumption cannot be overemphasized owing to the zoonotic potential of these species. Hence, aquaculture production in Ghana, focused on increasing consumption of fish using methods that minimizes risks to public health is highly critical, particularly that which ensures maintaining good water quality and minimum contamination by handlers during, feeding, grading and netting.

\subsection{Conclusion}

The present study concluded that bacterial infections, particularly with streptococcus species are prevalent in aquaculture farms in Ghana. Co-infections was also found to be prevalent with six bacteria pathogens in samples. The molecular tools used were very sensitive, specific and rapid enough in identification of disease pathogens even in asymptomatic fish. The multiplex assay described here using syber-mix reaction protocol on the three target species has not yet been reported elsewhere. The study thus constitutes an advancement in the available diagnostic methods and the overall technical know-how in fish disease diagnosis in Ghana. Effective epidemiological studies and disease control is hinged on identification of pathogenic species using a fast and reliable methods of diagnosis, hence, the protocol described this study could be used for routine diagnosis of fish diseases on commercial basis.

\section{Declarations}

\section{Acknowledgement}

The Authors wish to thank USAID/UCC Fisheries and Coastal Management Capacity Building Support project (Project Implementation Letter: PIL No.: 641-A18-FY14-IL\#007) for Providing funds for this research. Our profound gratitude also goes to CSIR-WRI, Biomedical and Public Health Research Unit for providing some logistics for laboratory analysis. 


\section{Funding:}

Funding for research was provided by USAID/UCC Fisheries and Coastal Management

Capacity Building Support project (Project Implementation Letter: PIL No.: 641-A18-FY14-

IL\#007).

\section{Conflicts of interest/Competing interests:}

The authors have declared that no competing interests exist.

\section{Availability of data and material:}

Available

\section{Code availability:}

Not Applicable

\section{Authors' contributions:}

Rhoda Lims Diyie carried out research and was involved in conception and design of study, acquisition of data, analysis and interpretation of data, drafting and revising of the manuscript. D. W. Aheto, M.Y. OseiAtweneboana, and K. Yankson were involved in the supervision of data collection, analyses, and revision of the manuscript critically for important intellectual content. Emmanuel Armah was involved in acquisition and analysis of data, drafting of the manuscript. All authors read and approved the final manuscript.

\section{Ethics approval:}

Not applicable

\section{Consent to participate:}

Consent for participation duly given by authors

\section{Consent for publication}


All authors have given their consent for publication of this article with Aquaculture International Journal

\section{References}

1. Alhassan, E. H., Agbeko, E., Kombat, E. O., Kpordzaxor, Y. (2018). Ectoparasite Infestation Of Nile Tilapia (Oreochromis niloticus ) in Cage Culture at Mpakadam, Ghana. Ethiopian Journal of Environmental Studies \& Management 11(5):514-525

2. Altinok, I. and Kurt, I. (2003). Molecular Diagnosis of Fish Diseases: a Review Turkish Journal of Fisheries and Aquatic Sciences 3: 131-138 (2003)

3. Ampofo, J. A. (2000). Studies on the occurrence and diversity of bacteria in fish culture system in Ghana with special reference to species pathogenic to fish and humans. PhD Thesis, University of Ghana.

4. Austin, B and D. A. Austin. (1999). Bacterial fish pathogens; disease of farmed and wild fish. Springer and praxis publishing Itd., Chichester, UK.

5. Austin, B. and Austin, D.A. (2007). Bacterial Fish Pathogens, 4th ed.; Praxis Publishing Ltd.: Chichester, UK, pp. 272-275.

6. Budiati, T., Rusul, G., Wan-Abdullah, W.N., Ahmad, R., Arip, Y.M. (2015). Microbiological Quality of Catfish (Clarias Gariepinus) and Tilapia (Tilapia Mossambica) Obtained from Wet Markets and Ponds in Malaysia. J Aquac Res Development .6:291 doi:10.4172/21559546.1000291

7. Cipriano, C. Rocco. (2001). Aeromonas hydrophila and Motile Aeromonas Septicemias of fish. Fish disease leaflet 68

8. Conroy, G., 2009. Estreptocococis en tilapia: prevalencia de las especies de Streptococcus enAmérica Latina y sus manifestaciones patológicas. En: Memorias de Streptococcus en pecesde aguas cálidas. 3, 15-20.

9. Decostere A, Haesebrouck F, Van DE (1999). Characterization of the adhesion of Flavobacterium columnare (Flexibacter columnaris) to gill tissue. Journal of Fish Diseases 22: 465-474.

10. Delannoy, C. M. J., Crumlish, M., Fontaine, M. C., Pollock, J., Foster, G., Dagleish, M. P., del Cerro, A., Márquez, I. and Guijarro, J. A. ( 2002). Simultaneous detection of Aeromonas salmonicida, Flavobacterium psychrophilum, and Yersinia ruckeri, three major fish pathogens, by multiplex PCR. Appl. Environ. Microbiol. 68:5177-5180.

11. Dissection, T. F., Marine, H., \& Fish, B. (n.d.). Fish Dissection.

12. Eldar A, et al (1995). Experimental streptococcal meningo-encephlitis in cultured fish. Veterinary Microbiology, 45: 33-40

13. Fadaeifard, F., Momtaz, H., Rahimi, E., and Mirzakhani, A. (2018). Detection of Streptococcus iniae and Lactococcus garvieae by multiplex polymerase chain reaction (PCR) in some rainbow trout farms of Iran, (January 2011). https://doi.org/10.5897/AJB11.2651

14. Heil N (2009) National Wild Fish Health Survey. Laboratory Procedures Manual, (5thedn), U.S.

15. Fish and Wildlife Service, Warm Springs, GA.19. 
16. Griffin MJ, Mauel MJ, Greenway TE, Khoo LH, Wise DJ. (2011). A real-time polymerase chain reaction assay for quantification of Edwardsiella ictaluri in catfish pond water and genetic homogeneity of diagnostic case isolates from Mississippi. J Aquat Anim Health. 23(4):178-88. doi: 10.1080/08997659.2011.637006. PMID: 22372245.

17. Houde, E.D. (1987). Fish early life dynamics and reruitment variability. American Fsiheries Society Symposium 2, 17-29

18. Ibrahem M D., Mostafa1, M. M., Arab, R. M. H. And Rezk, M. A. (2008). Prevalence of Aeromonas Hydrophila Infection In Wild And Cultured Tilapia (O. niloticus) In Egypt. . $8^{\text {th }}$ International Symposium on Tilapia in Aquaculture, pp 1257-1271

19. Jimenéz, A.P., (2010). Disertación de maestría en microbiología. In: Detección De Streptococcus Agalactiae Por PCR En Tejidos De Tilapias Rojas (Oreochromis spp.) Menores De 20 g. Universidad Nacional de Colombia, Colombia, pp. 101

20. Karunasagar, I., I. Karunasagar and S. K. Otta. (2003). Disease problems affecting fish in tropical environments. J. Applied Aquaculture. 13(3/4): 231-249. Emerging diseases in tilapia: future prevention methods will alleviate the economic threat. https://ag.arizona.edu/azaqua/ista/ISTA7/Abstracts/CedricKomar_abstract_ISTA7. (Accessed March 2018)

21. Kompanets, E. V., N. M. Isaeva and I. A. Balakhnin. (1992). Bacteria of genus Aeromonas and their role in aquaculture .Microbial .Zh; 54 (4): 89-99.

22. Kotob, M.H., Menanteau-Ledouble, S., Kumar, G. et al. (2017). The impact of co-infections on fish: a review. Vet Res 47, 98 https://doi.org/10.1186/s13567-016-0383-4

23. Kouamé, A., Céline, N., Koco, S., and Laurent, A. Y. (2014). Aquacultural Potential of Silver Catfish Chrysichthys nigrodigitatus ( Lacepede, 1803 ) Bred in Fresh and Brakish Water in Three Rearing Systems: Enclosures, Cement Tanks and Earth, Advances in Bioresearch, 165-171. https://doi.org/10.15515/abr.0976-4585.5.2.165171

24. Kumari, S., Prasad, B.N. Kumari, G., Modi, G.S. Quasim A. and Sinha B. K. (2001). Occurrence Of Staphylococcus In Rohu, Labeo Rohita, Collected From Patna Fish Market. Indian J. Anim. Res., 35 (1): $56-58$

25. Mangala A. N., F. E. Martin, N. A. Jacques, N. Hunter (2002). Determination of bacterial load by realtime PCR using a broad-range (universal) probe and primers set. Microbiology Society. Volume 148, Issue 1 https://doi.org/10.1099/00221287-148-1-257

26. Mata, A. I., Gibello, A., Casamayor, A., Blanco, M. M., Domínguez, L., Ferna, J. F., and Icrobiol, A. P. P. L. E. N. M. (2004). Multiplex PCR Assay for Detection of Bacterial Pathogens Associated with WarmWater Streptococcosis in Fish, 70(5), 3183-3187. https://doi.org/10.1128/AEM.70.5.3183

27. Maaser, C., Kagnoff, M. F. (2002). Role of the intestinal epithelium in orchestrating innate and adaptive mucosal immunity. American Journal of Tropical Medicine and Hygiene, 77(4), 591-592. https://doi.org/77/4/591 [pii] 
28. Mente, E., Pierce, G. J., and Neofitou, C. (2006). Effect of Feed and Feeding in the Culture of Salmonids on the Marine Aquatic Environment: A Synthesis for European Aquaculture, https://doi.org/10.1007/s10499-006-9051-4

29. Meyer F. P. (1991).Aquaculture disease and health management. Journal of Animal Science. ;69(10):4201-4208. [PubMed] [Google Scholar]

30. Muzquiz, J.L. Royo, F.M. Ortega, C. De Blas, L Ruiz, I. J. L. A. (1999). Pathogenicity of streptococcosis in rainbow trout ( oncorhynchus mykiss ): dependence on age of diseased fish, 19(3), 114-119.

31. Nils kautsky, Patrik Romback, Michael Tedengren and Max Troell. (2000). Ecosystem perspectives on management of disease in shrimp pond farming. Aquaculture,19: 145-161.

32. Noga E. J. (1996). Fish Disease: diagnosis and treatment. Moshy-Year book, Inc, Naples, Tokyo, New York pp. 294.

33. OIE (World Organisation for Animal Health), The Disease. Reprinted courtesy of OIE Diagnostic Manual for Aquatic Animal Diseases, aquaculture, Paris, France.

34. OIE (2013) Aquatic Animal Health Code. (16thedn), World Organisation for Animal Health, Paris, France.

35. Peakall R, S. P. (2012). GenAIEx 6.5: genetic analysis in Excel. Population genetic software for teaching and research. An Update. Bioinformatics.

36. Raymond M, R. F. (1995). GENEPOP: a population genetics software for exact test and ecumenicism. J. Hered, 86, 248-249.

37. Post, G. W. (1989). Text book of fish health J. F. H publication, Inc Ltd. 211 West Syvania Avenue Neptune city NJ 00753.

38. Real, L. A. (1996). Sustainability and ecology of infectious diseases. Bioscience 46, 88-97.

39. Sheehan, B., Lee, Y.S., Wong, E.S., Chan, J., Labrie, L., Komar, C., Wendover N., Grisez, L., (2009). Aquavac Strep Sa: Una novedosa vacuna para el control de las infecciones causadas por Streptococcus agalactiae Biotipo 2 en tilapia de granja. En memorias: Manejo de Streptococcus en peces de aguas cálidas, pp. 21-26.

40. Sifa, L and Mathias, J. A. (1987). The critical period of high mortality of larvae fiah-A discussion based on current research. Chin J. Ocean Limnol.5:1 pp 80-96

41. Suthikrai, N. P. (2012)(n.d.) In Vitro Efficacy of Red Kwao Krua (Butea superba Roxb.) Extract Against Streptococcal bacteria Isolated from Diseased Tilapia (Oreochromis niloticus), 42(1), 101-105.

42. Swann L. M. and Randy White, D.V.M. (1914). Diagnosis and Treatment of "Aeromonas hydrophila" Infection of Fish. Aquaculture Extension, Disease Fact Sheet AS-461

43. Takyi R. Nunoo F. K.E., Ziddah,P. and Oddoye J. (2012). Occurrence of bacterial infections in two commonly cultured fish species on two fish farms in Southern Ghana. World Journal of Biological Research. 12pp.

44. Zhang, D., S. A. Moreira, C. Shoemaker, J. C. Newton, D. Xu, (2016). Detection and quantification of virulent Aeromonas hydrophila in channel catfish tissues following waterborne challenge, FEMS 
Microbiology Letters, Volume 363, Issue 9 fnw080, https://doi.org/10.1093/femsle/fnw080

45. Zorrilla, I. M., M. S. Chbrillon, Arijo; Diaz-Rosales, M. Martinz-Manzanares, M. C. Balebona and M. A. Marinigo. 2003. Bacterial recovered from diseased cultured gilhead sea bream (Sparus aurata L.) in southeastern Spain. Aquaculture. 218: 112

\section{Tables}

Due to technical limitations, tables are only available as a download in the Supplemental Files section.

\section{Figures}

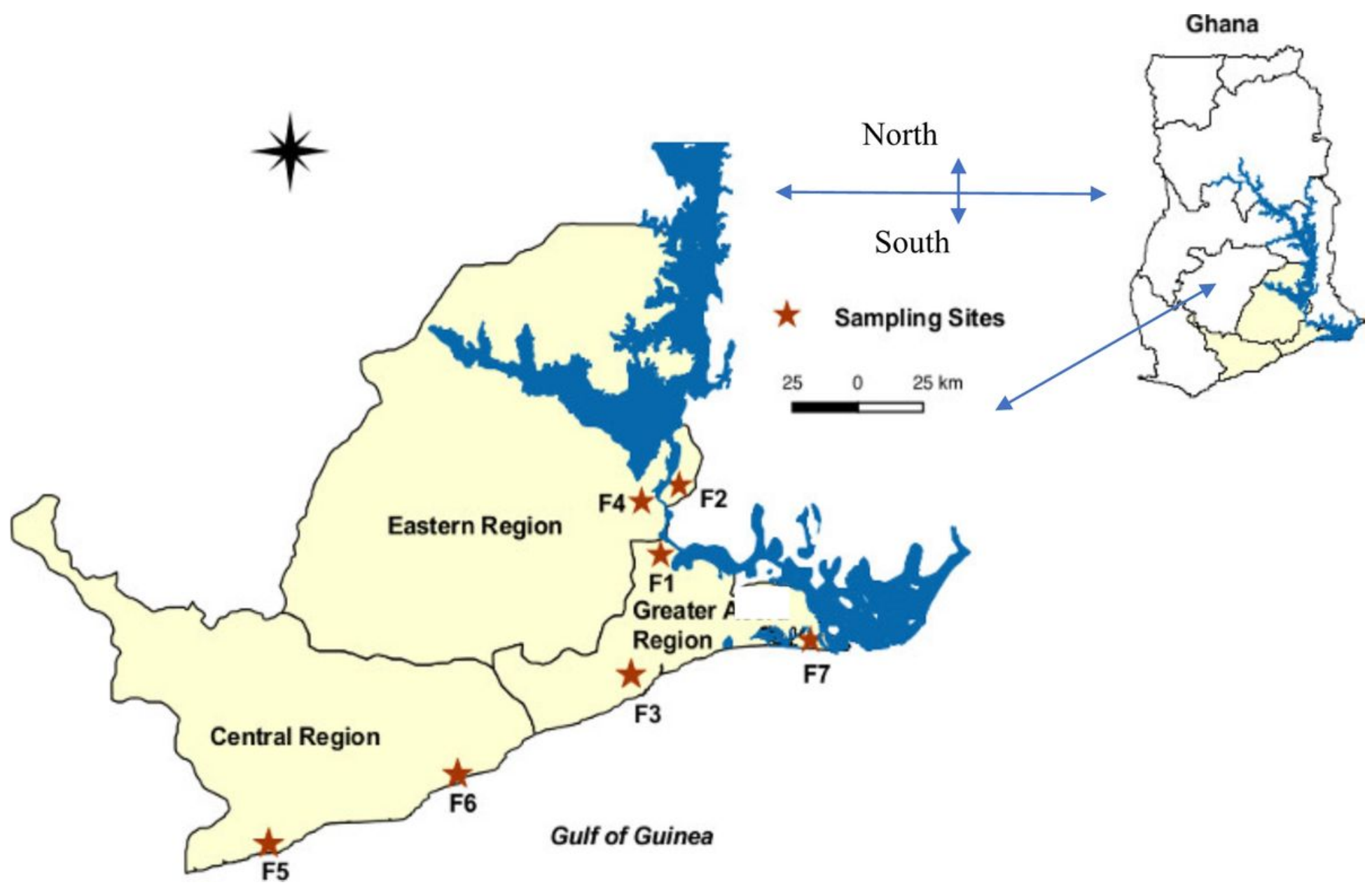

Figure 1

Locations of fish farms in Ghana sampled for disease diagnoses Note: The designations employed and the presentation of the material on this map do not imply the expression of any opinion whatsoever on the part of Research Square concerning the legal status of any country, territory, city or area or of its authorities, or concerning the delimitation of its frontiers or boundaries. This map has been provided by the authors. 


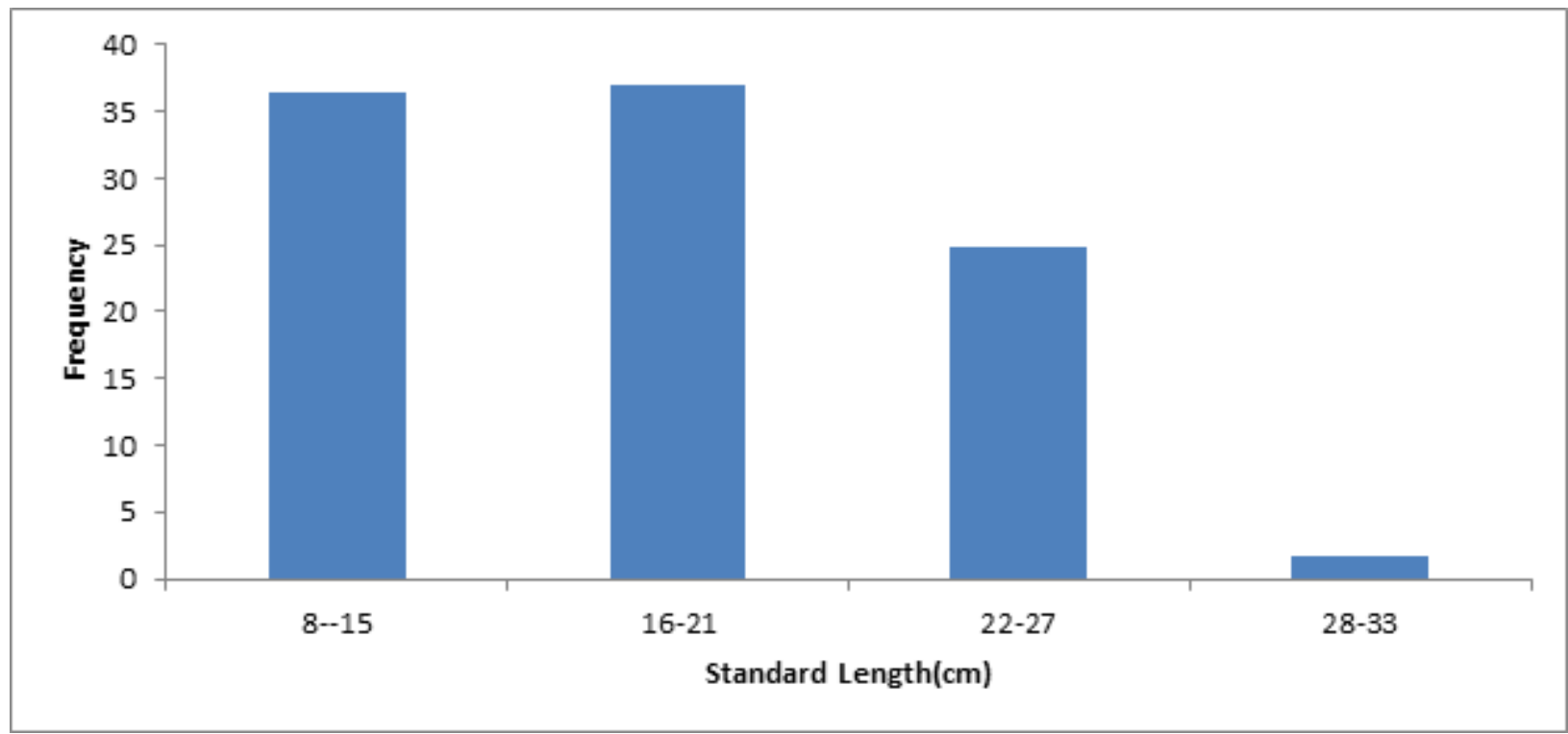

Figure 2

Distribution of Average Standard Length of Nile tilapia obtained from all Farms

A.

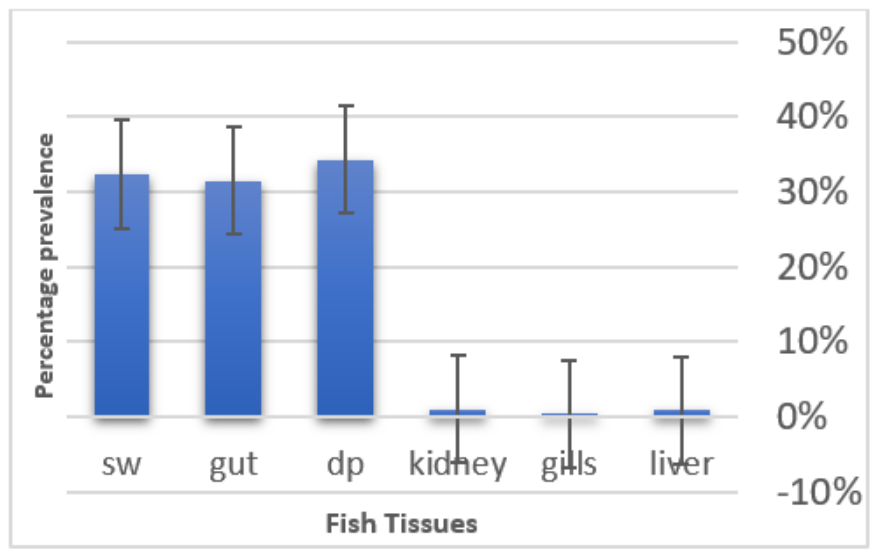

B.

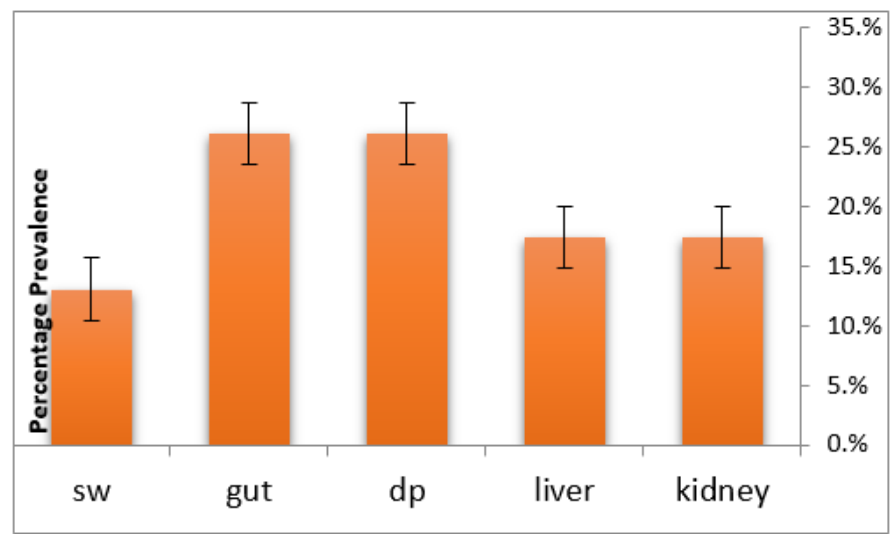

\section{Figure 3}

Prevalence Rate of Bacteria in Various Tissue Samples of Nile Tilapia (A) and Catfish (B) Cultured in Ghana. (sw is skin washes, and dp is diseased portions) 


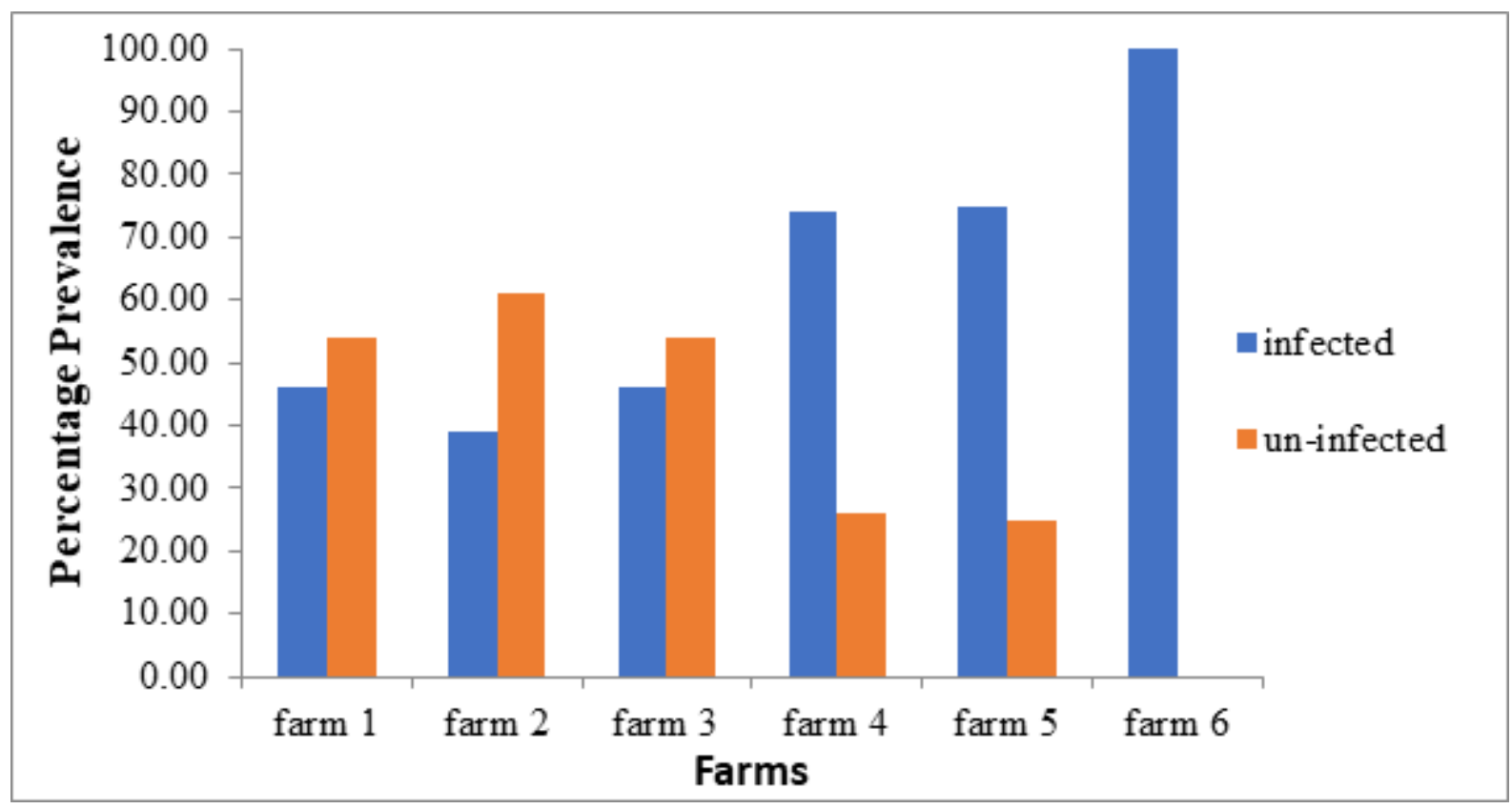

\section{Figure 4}

Prevalence Rate of Bacterial Infections among Six Fish Farms in Ghana

\section{$\begin{array}{llllllllllllll}M & 1 & 2 & 3 & 4 & 5 & 6 & 7 & 8 & 9 & 10 & 11 & 12 & \text { WC }\end{array}$}

\section{$1000 \mathrm{bP}$}

\section{$500 \mathrm{bP}$}

\section{Figure 5}

Gel image from PCR amplification for detection of six species of bacteria in a singleplex reaction. ( Lanes 1 and 9 are positive for Aeromonas hydrophilia (190bp), Lanes 2 and 4 are positive for S. iniae (1100bp), Lanes 3 and 8 are positive for $S$. aureus (700bp), Lanes 6 and 7 are positive for $S$. agalactiae (220bp) , Lanes 5 and 11 are positive for Edwardsiella ictalueri(407bp), and Lane 12 is positive Flavobacterium columnare (504bp), NC is negative control and M is Molecular marker). 


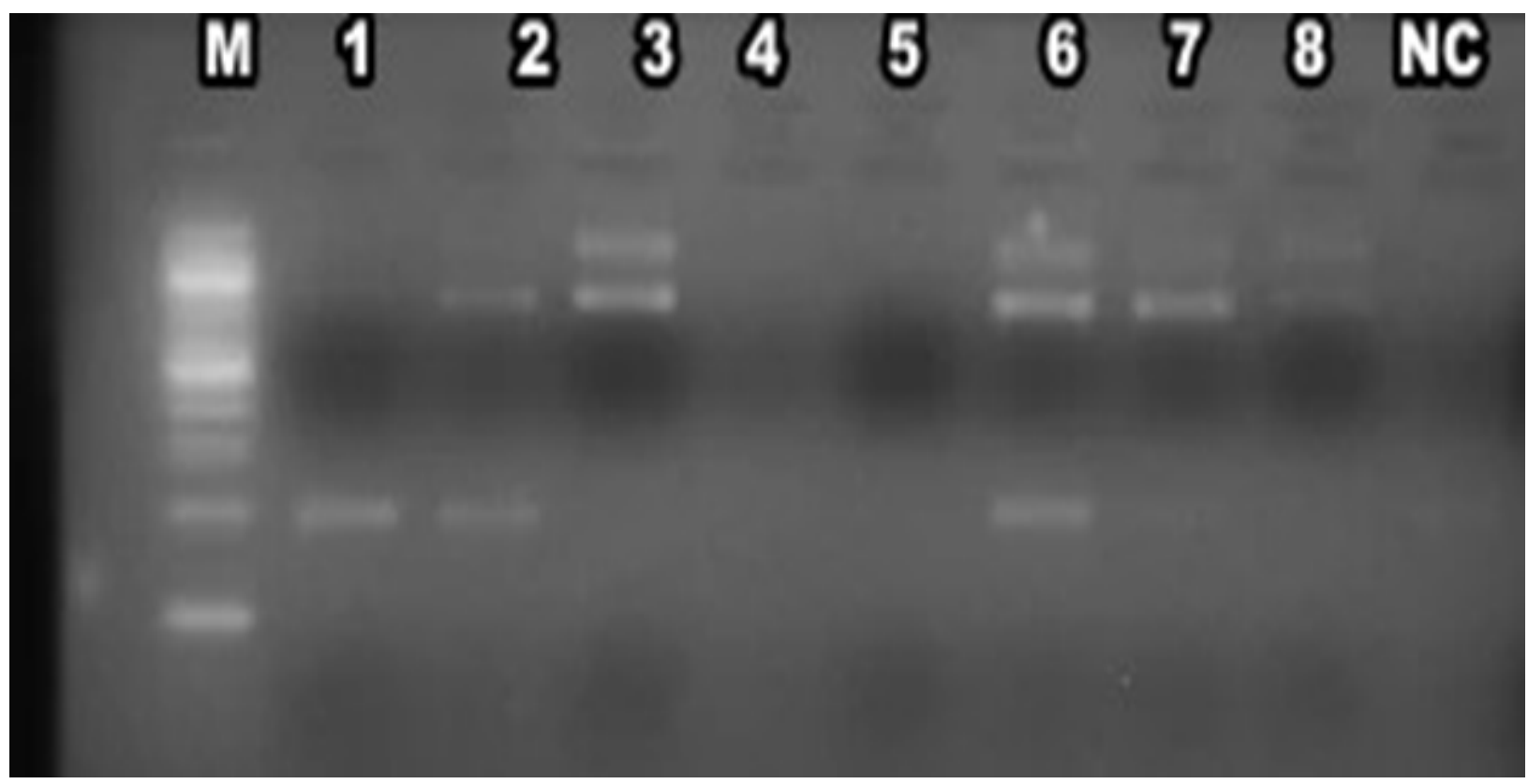

\section{Figure 6}

Multiplex PCR Detecting 3 target Bacteria of Aquaculture Importance: (Streptococcus agalactiae (200bp), Staphylococcus aureus (700bp) and Streptococcus iniae (1100bp). Sample 1: amplified for S. agalactaie, sample 2 amplified for S. agalactiae and S. aureus, samples 3, 7 and 8 each amplified for both S. iniae and S. aureus whiles sample 6 shows amplification for all three bacteria species. Samples 4 and 5 didn't amplify for any bacteria. NC is negative control and M is Molecular marker.

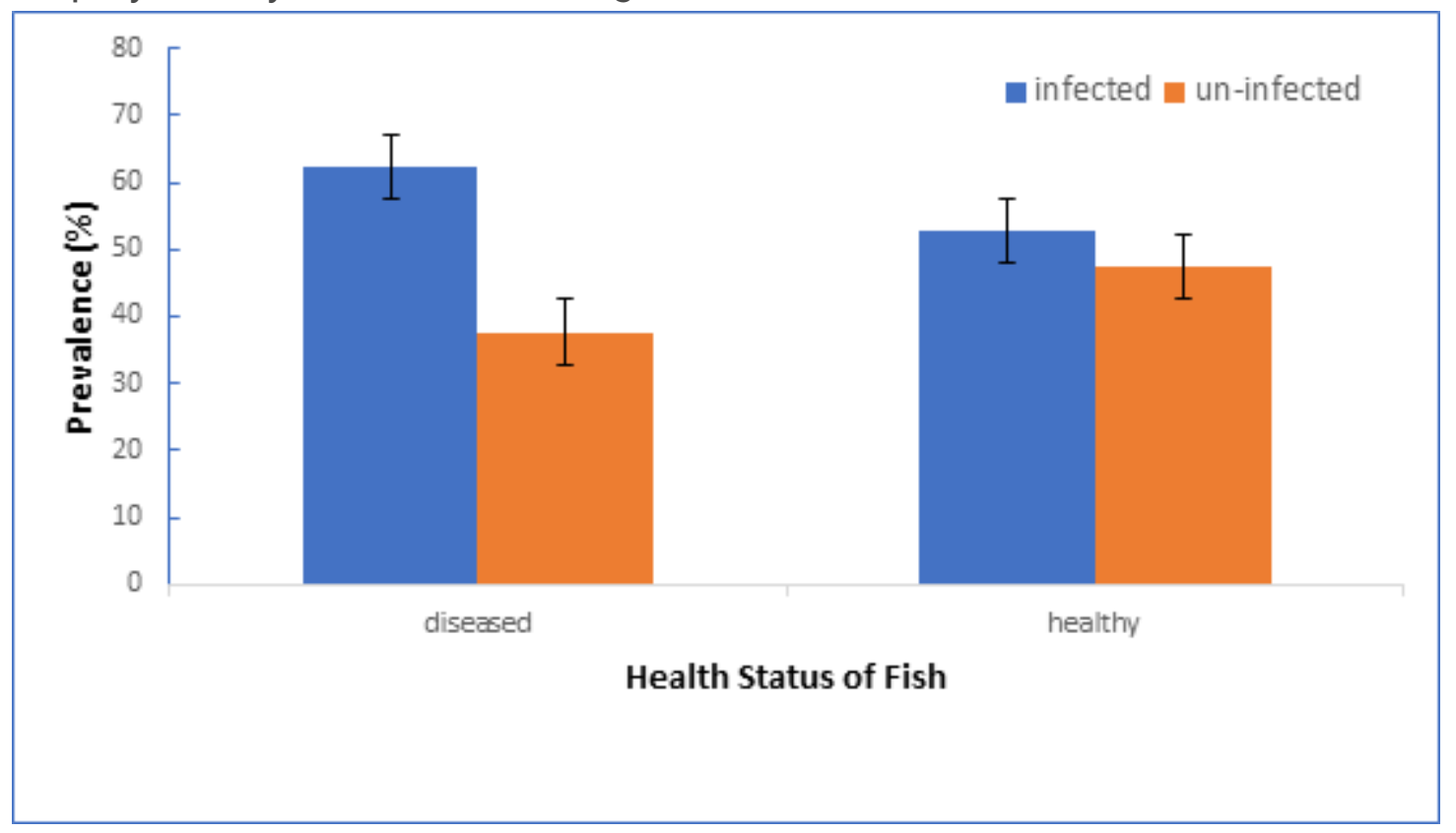

Figure 7

Prevalence Rate of Infections in Fish per their Health Status

\section{Supplementary Files}


This is a list of supplementary files associated with this preprint. Click to download.

- Tables.docx 